\title{
From Betrayal to Resistance: Working- class voices in Russia today
}

\author{
Jeremy Morris, Aarhus University
}

\begin{abstract}
This article analyses three aspects of working-class life in Russia that add to the debate about global working-class responses to disenfranchisement and 'crisis'. Firstly, it highlights how traditionally workers have been atomised as a group due to the demotivating effects of postcommunist transition itself. Nonetheless, there remains a coherence of shared values and grievances rooted in the still-living memory of the communist-era 'social contract', and workers' current experience of harsh anti-labour industrial relations and state indifference. Thirdly, despite seemingly no outlet in oppositional politics, there are signs of resistance, if not revolt. These range from the informal 'black' economy as 'exit' from formal work, smallscale labour protests and the organising of new independent labour unions in transnational companies, and the rising political consciousness of working-class voters who look for any 'alternative' to the ruling party - including the popular-nationalist far right, and abstention from voting all together. The conclusions highlight the convergence of workers' and ordinary people's grievances in Russia in an unpredictable environment where multiple issues may coalesce and then spiral out of control. Recent examples of such issues have included labour unrest due to wage arrears, political corruption, road taxes on truckers, and the demolition of housing in city centres.
\end{abstract}

Keywords Russia, working-class politics, authoritarianism, labour, protest, trade unions

Ever since the end of the Soviet Union in 1991 a joke has been going around Russian factories and workshops: 'In the Soviet Union, ordinary people always knew the authorities were lying about communism; now they realise that they were telling the truth about capitalism.' This joke continues to speak to the universal feelings of betrayal among workers during the post-communist transition that seems to have no end in sight. For many they compare their standard of living now unfavourably with the past. While they are not nostalgic for the political realities of communism, the failure of the last twenty-five years to provide an improvement in the conditions, pay and general quality of life for workers and their families, means working-class people's grievances should be ripe for populists to prey on.

However, in this article, I focus on three aspects of working-class life in Russia that add to the debate about global working-class responses to disenfranchisement and 'crisis'. To do this I make use of research materials gathered through ethnographic participant observation and interviews, conducted in industrial communities in Russia since 2009.

Firstly, I outline the political-economy context in Russia. The authoritarian government carefully controls political expressions of dissent, whether through political parties, protest or trade union activities. In addition, workers are relatively atomised as a group - this is due to the extremely impoverishing and demotivating effects of post-communist transition itself. One of the results of the long process of relative de-industrialisation after 1991 is the fall 
back of workers into patterns of subsistence and survival that appears to preclude organisation and resistance.

Nonetheless, a second aspect is the coherence and continuity of working-class life and consciousness, despite the dominant view of atomised workers. We need to look at the relative geographical concentration and continuity of working-class communities (in rust-belt cities) and the coherence of their shared values and grievances. These are rooted in the stillliving memory of the communist-era 'social contract', and workers' current experience of harsh anti-labour industrial relations and state indifference.

Thirdly, despite seemingly no outlet for frustration in oppositional politics, there are signs of resistance, if not revolt. These range from the informal 'black' economy as 'exit' from formal work, small-scale labour protests and the organising of new independent labour unions in transnational companies, and the rising political consciousness of working-class voters who look for any 'alternative' to the ruling party - including the popular-nationalist far right, and abstention from voting all together.

The conclusions highlight the convergence of workers' and others' grievances in Russia. While organised linking up of disparate political, social and labour protests is unlikely, their growing frequency and the febrile atmosphere of authoritarian politics, makes for an unpredictable environment where there is always the possibility for multiple issues to coalesce and then spiral out of control as a locus of common opposition leading to regime transformation. Recent examples of such issues are the corruption of self-enriching elites, road taxes on truckers, and the demolition of housing in city centres. Informal labour protests due to wage arrears are increasingly important too.

\section{The political-economic context of Russian workers}

Russia is an authoritarian state dominated by a small political elite. Elections are manipulated to ensure a large majority for the government, and the ruling political party and parliament is largely a rubber-stamp affair. The government does not hesitate to use its extensive security apparatus to stifle and punish independent civic organisation, particularly if this results in visible public protest. The position of workers who try to organise and protest their conditions is very difficult. Since the Labour Code of 2001, union powers have been severely curtailed. Strikes now must be approved by all employees, not just members. In many sectors strikes are illegal. The law also makes it difficult for new active unions to challenge or replace unresponsive and bureaucratic traditional 'Soviet-style' unions (Olimpieva: 2012, Ashwin and Clarke: 2003). The most militant unions have been targeted under antiextremism laws by the security services.

A short historical and comparative contextualisation of Russian labour since 1991 is necessary. Christensen (2016), in an overview of the Russian working-class, characterises the story of the Russian economy as 'calamitous collapse' in the 1990s. Economic shock therapy in the 1990s saw factories - whose whole production logic was previously based on quantitative outputs - rapidly exposed to market pricing and real costs. While many factories and concerns survive in severely truncated form, and strategic military-industrial factories were protected to a degree, only metals and hydrocarbons sectors have gained their share in the economy, It is fair to speak of wholesale deindustrialisation; industrial production is still only $85 \%$ of its 1990 level and seven million industrial jobs have been lost (Christensen: 2016). This is a $16 \%$ fall in the industrial labour force, in contrast to the US, where 4.5 
million jobs were lost in the same period - or a 5\% fall (Christensen: 2016). It is often thought that the experience of post-communist transition meant mass unemployment, but it more resembles the slow loss of industrial lifeblood as enterprises used natural wastage or fired women to reduce headcounts (unemployment reached a high only in 1998 at 14\%). The massive destruction in the purchasing power of incomes is much more keenly felt in the living memory of working people. People cannot forget the real terms reduction of those incomes as they were left unindexed throughout the high-inflation 1990s and early 2000s, and in some insolvent firms' workers were affected by long-term wage arrears. This is important in the present, as Russians face a similar downturn in purchasing power of incomes after the sustained oil price fall in 2014 and other factors such as the Ukraine crisis.

In Russia, the socialist period was generally characterised by secure, formalised jobs, and an extensive system of social benefits for workers and their families. These benefits implicitly provided compensation for poor working conditions and no political representation (Cook: 1993). In the post-communist period, ongoing market deregulation has resulted in the erosion of standard employment practices, growing underemployment, sporadic wage arrears, an increasing number of informal and semi-formal jobs (Bizyukov: 2016), less secure jobs, a lack of the development of legal and social rights of workers, arbitrary wages, a sharp decline of social benefits, and a trade union system that is largely trapped in Soviet-style patterns of action (Ashwin and Clarke: 2003, Clarke: 1995; Stenning et al.: 2010). As a result, in-work precarity is the norm for many working-class Russians. However, the inherited values and prior experiences of workers such as the memory of a social wage are still important. In the recent communist past, standard employment provided significant social benefits such as access to housing, canteens, kindergartens, etc. In addition, the nature of shop-floor relations was often highly specific: many workers experienced relatively low or intermittent levels of work intensity, with piecework being the exception not the rule, as well as protection from overly individualised relations with management by the brigade system (Clarke: 2007, 193).

However, living standards and the memory of a social contract in the past require more contextualization. This was very much a minimum guarantee with numerous flaws: people had enough to eat, but spent a lot of time and resources in getting more than basics. In the 1980 s even staple goods became hard to source without exhaustive queuing or endless personal networking. Workers benefited from factories building housing stock right to the end of the Soviet period, but the quality of dwellings was poor. For most families a flat consisted of a single room, a small kitchen, and a toilet/bathroom. Medical care was universal, but for those who were not members of the elite, it was of very low quality. Other social guarantees and benefits were nominally available, but in practice often inadequate, including medical care and pensions.

The point is that as an inflection point, the collapse of the USSR was understandably interpreted as the beginning of 'Western' standards of living for all. The transition of the 1990s and massive structural adjustments of the economy - largely borne by workers, was the 'waiting period' - highlighted by Sarah Ashwin in the title of her book on workers as the 'anatomy of patience' (1999). Particularly for people in blue-collar jobs, the last twenty-five years have illustrated the grim reality behind that joke about communism and capitalism - the massive economic transition to a system at least resembling market capitalism. From a system promising full employment, secure jobs, social mobility and decent in-work benefits, if not pay, many factories closed completely, some soldiered on through the 1990s. However, during Putin's first tenure from 1999-2008, most people experienced sustained aboveinflation boosts to their take-home pay. 
The 'Putin' era, from 1999, is therefore broadly a marker of the end of the 'waiting in line' oil prices rise and social expenditure increased sharply. But this faltered in 2009 after the global financial crash, and then when oil prices sustained their decline in 2014 the tap was turned off and austerity politics as well as devaluation hit industrial workers and governmentsector workers hard. Just to give an example, a cement factory worker outside Moscow earned \$500 a month (equivalent) in 2010 and could (just) support a family, as long as that family already owned a home. ${ }^{1}$ In 2016 because of stoppages due to falling demand, and compounded by currency devaluation, the same worker's pay is $\$ 125$. $^{2}$ Add to that high inflation in staple goods and you have a situation where many Russian workers are experiencing the worst reduction in standards of living in living memory. Indeed, they pushed back into third-world levels of subsistence. Combining numerous data sources and taking a national overview of the situation, Strzelecki $(2017,10)$ notes that 'the number of individuals who declare that they have too little money to buy enough food and those who cannot afford to buy clothes [...] amounted to around $40 \%$ of the population. The low paid workers in some regions are now spending up to $80 \%$ of their pay on basic food staples (TsEPR: 2016, 5).

The patient waiting metaphor is apt also in a comparative sense. The perceived injustice of 'line cutters' for the American Dream while workers endure the ravaging effects of neoliberal reform is key to Arlie Russell Hochschild's work on the US context (2016). The rejection of political-business-as-usual has led to Trump's victory there, but even in Russia, there are limits to the authoritarian state's capacity to defuse discontent based on injustice and inequality indefinitely, particularly at a time where these issues can only grow worse and become more visible. Patience may be a working-class virtue, but it is not a renewable resource.

\section{Rust-belt Coherence and Continuity}

The Soviet industrial project involved mass, and massively coercive, movements of people to formerly empty spaces for the creation of a primary industrial base unrivalled in scale and rapidity of development. These spaces were usually the site of raw materials like iron ore. This led to the growth of both small and large 'mono towns' where most employment related to a single activity or enterprise - coal mining, aluminium smelting, or later on, secondary production: automobile production, military hardware, etc. However, unlike the 'rust belts' of other global north countries, most of Russia's industrial towns are spread out all over the country, rather than in roughly identifiable regions (such as the North in the UK, the upper Mid-West in the USA, or the Ruhr in Germany).

\footnotetext{
${ }^{1}$ The economic significance of home ownership in Russia requires some elaboration. After the collapse of the USSR, many were able to privatize the flats they had formerly rented from the state. Until the late 2000s, utility and ground rents were subsidized heavily. The withdrawal of such subsidies recently, means even those older workers lucky enough to own a home feel significant financial pressure, let alone younger people, who, like in most industrialized countries elsewhere, have little chance of ever owning a home.

${ }^{2}$ Average wages for all employees have fallen by around 50\% in dollar terms between 2013-2016 (Strzelecki: 2017). It is also necessary to note that outside the big cities, many white-collar employees would have comparable incomes from main employment, forcing them to seek parallel 'moonlighting' opportunities elsewhere. In addition, everyday costs like food, energy and transport are now approaching those in Western Europe - thanks to sustained high inflation of around 8-10\% since the 2000s.
} 
The meaning of 'rust belt' in Russia also has a different temporal meaning. Largescale industrial migration resembles that which occurred in the West, however, in Russia this process is still a 'living' phenomenon - i.e. people still have a keen sense that they come from a family that migrated large distances due to employment within recent living memory (in contrast, for example with people living in Detroit today, for whom the 'memory' of moving from the South in the 1940s or 50s may be less meaningful).

Mono town settlements functioned as the fiefdom of a single (state) employer. Like in the US 'company city', the enterprise played an exceptionally important role in the provision of systems of welfare and patronage. Housing was built and maintained by the factory organisation, and leisure, health and other amenities were funded from the same source. Many mono town enterprises acted almost as 'total social institutions' and 'states within states' (Clarke 1993: 26). In the present there is still the expectation among inhabitants of a kind of social contract between the state and labour. There is also the geographical isolation of many industrial settlements from big-city life - 'islands' of factory settlements in a sea of forests and rural lands. With the exception of a few key military enterprises, like the weapons producers, the state is in no position to restructure blue-collar employment to sustain living wages, let alone repair the loss of social benefits enjoyed in the late Soviet period.

Nonetheless, while beyond the horizon of experience to the millions living in the relatively comfortable cosmopolitan centres of Moscow and St Petersburg, and despite now making up only $25 \%$ of urban space in Russia, these extractive and processing centres still provide about $30 \%$ of GDP (the majority of the rest coming from gas and oil). Only a relatively small number of large mono towns exist (with populations over 100,000) although ten million people live in them. The typical mono town is somewhat smaller. 14 million Russians $(10 \%$ of the country's population) live in these 'small cities' (less than 100,000 inhabitants), and the isolated-islands pattern of industrial urbanisation remains significant. These communities experience relative isolation, but also provide a sense of self-sufficiency and local identity, however illusory these may be in reality. However, the press and even sociologists and demographers approach the issue in terms of an urban hierarchy: these places are a 'secondary Russia'; the main 'problem' is the 'failure to adapt' by these inhabitants. They are seen are politically and socially 'backward'. Like the anti-working-class vocabulary in the West, a picture of hopeless 'deplorables' dominates. Such people's low life expectancy is seen through their failure to 'adapt' to new market realities as much as it is the fault of reforms themselves. Ironically, it is the relative isolation and sense of victimhood that support a sense of local identity and class-consciousness in these places. This worker is as significant as national or political allegiance - being more likely to feel a sense of solidarity as the exemplary class of economic, social and psychological 'losers' of post-communist transition. Where the factories survive in some form, people's attachment to them remains significant in anchoring identity (Morris: 2016).

Many workers retain household rural land plots they were allocated by the factory in communist times. Even more important today for survival, workers cultivate them in their free time, retaining a precious link with the past. 'Insurance policies' and self-provisioning are just as important ideas and values for working-class people as in the past. What is often overlooked in terms of precarious workers' real adaptation to conditions, is the ubiquity of the informal economy. This is the cash-in-hand, unskilled or skilled work in construction, truck driving, small trade and numerous other working contexts that are everywhere available, yet are invisible to the tax authorities. In particular, with the relative isolation of mono towns, informal economies are often tolerated by local authorities who know very well the few other opportunities for survival. While informal work is often interpreted as 
particularly precarious, exploitative or self-exploiting (Williams: 2008 Kalleberg: 2009, Waite: 2009), for underemployed workers, the informal economy is an ever-present insurance policy against destitution, and, more importantly, an alternative to formal employment. The 'black' economy is advantageous to both the state and individuals and may encompass up to $50 \%$ of GDP. The state benefits, particularly politically, as informal activities, e.g. 'gypsy' cab driving or day labouring, provide a buffer against unemployment and obviate the need for meaningful social security for the working-age population. On the other hand, informality at all levels is a major barrier to the Russian state attaining any kind of meaningful tax base from employment. Importantly, it is also a barrier to the institutionalisation of the structural power of workers in independent union movements. The 'turnover' of workers in even the factories with the best pay and conditions is exacerbated by the availability of alternative informal work. Thus, where effective and politically motivated unions do spring up, despite the obstacles, such as in the automotive industry, they are severely hampered by the instability of cadres and the 'escape route' from poor working conditions available to workers in informality.

\section{Populist politics and the silent majorities}

On the face of it, Putin's 'system' of loyalty, patronage and coercion has effectively sidelined any potential militancy by workers. While taken separately the mechanisms are relatively weak (anti-union laws, political-co-option), they pale into significance in comparison to the one big success and the one big truth of the Russian political-economy. And this relates to the whole population, but is most 'expressed' among workers. The 'success' is the careful management of the media and the general population's exposure to news. Add the age-old accelerant of xenophobia and nationalist fervour. A dollop or two of war helps. Some of my working-class research participants whole-heartedly support all the current military adventures and nationalist rhetoric. This type of effective populist distraction takes real effort, but is all the more effective in a state where most people get information from the television alone. Despite these disconcerting factors, there are a number of reasons to be hopeful about working-class mobilisation, resistance and agency in Russia today.

\section{Voices: 'exit', the ballot box, and protest}

The first category is informal economy as a 'voice' or 'exit' for working-class people, that merely by its existence and ubiquity remains a challenge to the stability of the state. As already mentioned, the 'black' or 'shadow' economy is problematic as an alternative to exploitative formal work. Untaxed and unregistered work, whether as a day labourer or selfemployed tradesperson, or 'gypsy' cab driver is often unpleasant, physically demanding, dangerous, offers poor returns, and is often typified by more extreme forms of exploitation (and self-exploitation). So why think of it as an 'alternative' at all? This is because of what some workers themselves tell us about leaving formal work to go 'underground'. A series of interviews I conducted with workers in 2010 revealed that they preferred the 'lesser evil' of informal work to factory work - whether in the old-style Soviet-era factories, or in the new hi-tech conveyor assembly lines of the auto plants located an hours-drive away near the regional capital. A key ethnographic interview revealed working-class ideas about the relative value of formal versus informal work:

I'd rather go out gypsy-cab driving. If it was easy enough to pay a decent wage, and more besides 20 years ago, then why not now under your capitalism? And really, everywhere is like that now, unfortunately, even the Cement works, even the Steelpipe workshop. It's all about 'have you done this, have you cleaned up the forklift park? The little bosses like to tyrannize everyone, trying to lord it over us and picking up on the 
stuff that's unimportant. Even at the limekiln these days you have to watch your back as everywhere there are narks who will grass on you to those Germans to get ahead. I was always considered a first-class worker. I can put a matchbox in place with my forklift but will I ever get on the Board of Honour for it? [interview 2010]

For other workers who left the factories for an unlicensed plastic window workshop, their choice of informal labour over formal was connected to values of craft, sociality, flexibility and autonomy. While the work was seasonal, they were paid more for this work on an hourly basis than in the factories. In the 'down' season, they spent their time doing day-labour jobs, working on the vegetable plot, or taxi-driving. One former car mechanic, 25 years-old, was responsible for all the lathe work and develops the theme of autonomy:

The pace is slower [than in the local factories] you haven't got people looking round the door to check on you. But then when the owner comes and says 'we need this order for tonight', then we'll work harder than we would in the factory. I worked in the Cement and no one there would break their back for avral [storming to meet a deadline]. On the other hand when you get a decent amount of hard cash for the job then the quality is going to be right. [interview 2010]

A 29-year-old, who had worked in a broiler plant as a technician continued:

There is an element of craftsmanship [masterstvo] to it, after all, there isn't if it is a proper production line. You just wouldn't have time for that at the Polymer. In fact the reason we have so much spare plastic for making drainpipes at the dacha is because there is so much wastage because of them rushing [laughs]. It's not like that here. Here the profit is in not wasting your material. Like we had a special order for a triangular window and it took us all day to work out how to seal the sharpest angled joint. But it gave us a sense of satisfaction. Time isn't always money. [interview 2010]

Those workers who left full-time factory work for taxi-driving and odd day jobs did acknowledge the precarious nature of this existence, but also stressed flexibility and the value of time:

Yes, sometimes I might only earn a couple of hundred in a shift [\$5]. That's local trips only and that only covers the petrol. You just eat potatoes and try not to think about it. But is it that different from working at the Cement, or in Kaluga at the Hardware wholesalers? [Vanya had worked there for a couple of years as a paint mixer and loader after quitting the security firm]. When I worked there I was being ordered around every day and my back ached even before I got there. You know I only got 18,000 roubles [\$550], even after I got made deputy manager of the paint department. Fuck that. In the taxi I am my own boss [sam sebe khoziain]... But on the nightshift when people are drunk then I can get a thousand a day, easy-more if you get on the right side of the dispatchers and get the out-of-town trips, to the district centre or Kaluga. It's probably the same money as the factory for half the hours. And I can easily fit in some moonlighting $[\mathrm{kalym}]$ jobs in between. You couldn't do that at the factory. [interview 2012] 
This final section discusses two other political categories of working-class response: firstly the ballot box and its boycott, and secondly, more active grass-roots labour protests and independent union activism as a substitute for left party-politics.

In the 1990s in Russia there was a more or less viable communist party opposition for whom many workers and others voted in elections until the 2000s, when it and other left-wing political forces were either co-opted or went into decline (March: 2002, 2009, Gel'man: 2007). Putin's initial popularity after the economic crises of the 1990s, along with high oil prices in the 2000 s, which allowed significant spending on social security, meant that a ruling party closely associated with the president, United Russia, dominated the electoral environment. Russia became a 'hegemonic' presidential party regime (Smyth et al.: 2007) where ordinary people willingly, reluctantly, or through work-place coercion, regularly turned out to vote for the president's party. From 2008 onward, Putin's 'party of power' increasingly resorted to populist rhetoric after the economic crisis and foreign policy distractions. While there were largely middle-class protests on a large scale in Moscow in 2012, the parliamentary elections in 2016 marked a clear limit to the sustainability of xenophobic and patriotic voter mobilisation. Officially the ruling party won by a landslide, but reputable political statistical analysis uncovered massive ballot stuffing and put the real turnout and ruling party vote-share at 36\% and 40\% respectively (Moscow Times: 2016). Hardly a ringing endorsement. Speaking to many working-class voters involved in my research, many had ceased to bother voting in the early 2000 s, unless their factory 'coerced' or incentivised them to do so (giving them a day off or a gift). Until 2006 they had the option to vote 'against all' candidates, and many did so. After this option was removed, it was postulated that other outlets of protest were likely (McAlister and White: 2008).

However, since the early 1990s there has been an alternative 'protest' party: the far-right nationalist party headed by a charismatic populist figure Zhirinovsky. Zhirinovsky's party regularly got around $10 \%$ of the vote in elections and as a political celebrity fond of outlandishly populist, often-racist statements using obscene language, Zhirinovsky has been a constant TV presence for twenty-five years. In 2016, while the communist vote collapsed, the far right got $17 \%$ of the (real) vote. While Zhirinovsky was previously seen as attracting mainly lower-middle class voters (Makarkin: 2007), my interviews with working-class voters saw an increase in those voting for him in 2016. A series of campaign ads focussed on inflation in food products, access to medicine and to housing finance. Coverage describing the party as merely 'nationalist' (Monaghan: 2016) distracts from the social and economic messages: 24 of the $28 \mathrm{TV}$ ads were on resonant working-class issues like caps on pay ratios between CEOs and workers, and policies to restrict debt collectors' activities - loose credit policies were likened to drug pushing.

In my small sample, non-voters remain the biggest group. 'We would vote for Zhirinovsky, but we don't vote. Why would we?' said a welder in his 50 s. This was the same person that in 2009 told me the Putin government would never care about 'people like him'. Others typically said, 'I don't know a single person who voted. I wouldn't even know where to go to vote.' Other people were more reflective and calculated - voting for the far right was a clear protest vote: '[the far-right party] are clowns but I voted for them because we need to send a message and there is no way of doing that. [Putin's party] has too much power. This is the last time they will win big.' These people are those who typically voted for Putin in the 'good' times of the 2000s. Corruption and inequality were high up on their agendas. 


\section{Grassroots protests and new union activism}

While electoral politics remains peripheral to working-class politics in Russia, the downward spiral of the economy has sparked sporadic and unorganised, yet significant, labour protest usually around issues of unpaid wages. This has involved miners in Rostov, farmers in Kuban, metallurgical workers in the Urals, a Ford plant near St Petersburg. This pattern was set back in 2009 when Cement workers in a small mono town near St Petersburg blocked a highway in protest at unpaid wages. Putin flew to the scene by helicopter and deflected blame on the billionaire owner.

The stifling electoral authoritarianism leaves no other available outlet for the expression of grievances. However, the most emblematic of these grassroots labour protests has been the 'passive' and informal strike action of truck drivers in 2015 and 2017. The truckers - often on self-employed contracts - faced large tax increases to use public highways. The protests also linked up labour grievances to corruption - a government crony was to make a large profit on collecting the new road tax. Like the more geographically localised protests, the truckers made their voices heard by blocking roads. However, unlike the isolated industrial communities that used this tactic, truckers were able to bring the protests much closer to the political heartlands of Moscow and St Petersburg. The first protest led to the government making concessions. The second set of protests are still carrying on as I write.

It's possible that, as with large scale urban protests, the security machinery of the Russian state is well-oiled enough to counter sporadic and relatively small-scale labour protests as they arise. By contrast, despite the securitisation of labour relations (where the security services get involved in union busting on a regular basis using 'anti-extremism' laws), new union movements may have a better chance of success in achieving their aims through activism. This is particularly true in multinational companies like Volkswagen that came to Russia relatively recently (Hinz and Morris: 2017). These plants have no existing unions and small groups of activists can make a significant impact. This was the case in Volkswagen in Kaluga city, studied by Hinz and Morris (2017). Activists, some of whom had contacts in Russian leftist movements, were supported by the Interregional Trade Union of Auto Workers (MPRA - which is affiliated to the umbrella organisation IndustriALL Global Union). They organised and mobilised workers effectively and became dominant in the plant. This allowed them, despite the anti-union laws, to lead negotiations with the management and conclude a favourable collective bargaining agreement. This led to wage increases and a reduction in temporary contract labour.

The Interregional Trade Union of Auto Workers (MPRA) is one of the newly emergent activist unions (Olimpieva: 2012). The MPRA originated in Ford, the first foreign carmaker that moved to the Leningrad region (surrounding St. Petersburg) in 2005. Further alternative unions joined the MPRA and gained a foothold in all the major automobile manufacturers and suppliers throughout Russia, in both domestically-owned plants as well as in foreignowned plants. MPRA is associated with the politicization of Russian labour unions since the 2000 s. The auto sector in particular has a history of militancy and independence dating from the 1990s (Mandel 2004). Indeed, the 1990s saw cycles of intense and desperate protest action beyond the organizational structures of traditional unions (Greene and Robertson: 2009). However, these attempts failed, partly because of internal organizational conflicts. Nonetheless by 2010 around three million workers were eventually organised in an umbrella independent confederation of unions - KTR (Confederation of Labour Russia).

Even before the sustained economic downturn after 2013, the lack of legal avenues for resolving labour disputes saw 'protests spill out of the factory gates and merge with other 
types of social protest' (Bizyukov: 2011, 6). These include actions less traditionally associated with labour disputes - hunger strikes, solidarity picketing blockading highways, and so on. These show both desperation on the part of workers (Greene and Robertson: 2009), but also the unpredictable course protests can take if not addressed quickly by the authorities either by concessions or coercion. At a round table of leading unionists and sociologists in St Petersburg in May 2017, there was discussion of the increasing frequency of spontaneous labour protests, regardless of the role of trade unions. The consensus was that labour and social protestors' interests and demands were converging in a politicised form (Bizyukov: 2017, Olimpieva: 2017).

\section{Conclusions}

Despite the authoritarian state and anti-labour laws, new activist unions like MPRA have an opportunity to use their expertise and networks to fill the 'left-center niche in Russian politics' (Olimpieva and Orttung: 2013, 3). As long as the oil price remains low, disorganised and organised labour will represent an 'immovable object' in the path of the Russian government's plans for the mobilisation of society according to crude nationalist rhetoric and the demotivation of political protest by means of heavy coercion.

Current research and monitoring shows the convergence and politicisation of labour and social protests because of the lack of economic progress since the late 2000s. Clément notes that many ordinary people who participate in local and less 'organised' protests 'have no previous activist experience, and may even have held negative attitudes towards activism and collective action before becoming involved' (Clément: 2015, 212). The same is true of labour protests such as the long distance truckers' dispute in 2016 (Bizyukov: 2017). Such a convergence indicates the possibility of workers, state employees such as teachers and medics, young people and pensioners making common cause in articulating grievances.

It is difficult to predict how the ongoing activation of working-class power in Russia will progress. It is increasingly impossible for the state to distract and deflect from the massive failure of economic and industrial policy in Russia. Politicians have made themselves hostages to fortune by closing off the option of the ballot box and the emptying of the political space of opposition. This is different from the 'revolt against the elites' context of democratic countries where populist politicians and parties are relevant, at least at the moment. On the other hand, the Russian example shows how even in an authoritarian political landscape, working-class people can make their voices heard - even if in the most desperate of circumstances. We should be attuned to the similarities as well as the seemingly differences of Russian protesting voices. Aleksandr Bibkov highlights the common themes of protest in Russia as attempts to activate 'dignity' and a sense of 'collective autonomy'. In this sense, there is hope that workers and others can make common cause (Bibkov: 2012: 283-4). We should also try to see Russian workers' struggles through a global lens of politics (Morris: 2017), and connect Russians' grievances, aims and values to other capitalist contexts throughout the world, the political differences of democracy and authoritarianism may be less important.

\section{Author Bio}

Jeremy Morris is an ethnographer of postsocialist societies and is Associate Professor of Global Studies at Aarhus University, Denmark. His research focuses on 'actually lived experience' in Russia and post-socialist states, particularly in relation to work, class and the 
informal economy. He has authored a number of books and articles including: Everyday Postsocialism: Working-class Life Strategies in the Russian Margins (Palgrave, 2016) He is the co-editor of New Media in New Eurasia (Routledge 2015); The Informal Postsocialist Economy: Embedded Practices and Livelihoods (Routledge 2014) and Informal Economies in Post-Socialist Spaces: Practices, Institutions and Networks (Palgrave 2015).

\section{Bibliography}

Ashwin, S. (1999): Russian Workers: the Anatomy of Patience, Manchester University Press, Manchester, UK.

Ashwin, S. and Clarke, S. (2003): Russian Trade Unions and Industrial Relations in Transition, Palgrave Macmillan, Basingstoke.

Bibkov, A. (2012): The Methodology of Studying "Spontaneous" Street Activism (Russian Protests and Street Camps, December 2011-July 2012), Laboratorium: The Russian Review of Social Research, vol. 4, no. 2: 275-284 (English summary of Russian-language article).

Bizyukov, P. (2011): 'Labor Protests in Russia, 2008-2011', Russian Analytical Digest no. 10427 October 2011, pp. 6-9.

Bizyukov, P. (2016): 'Precarious Employment in Russia: a Form of Degradation in Labour Relations', in Supriya Routh, Vando Borghi (eds.). Workers and the Global Informal Economy: Interdisciplinary perspectives, Routledge, London and New York. 174-189.

Bizyukov, P. (2017): 'Sotisal'noe prostranstvo trudovogo protesta: aktory i vzaimodeistviia' [the social space of labour protest: actors and interplay'], conference panel organised by Irina Olimpieva: 'Po tu i etu storony barrikad: podkhod k issledovaniiu sotsial'no-trudovykh protestov v Rossii' [On that and this side of the barricades: an approach to researching sociallabour protests in Russia], Centre for Independent Social Research Conference 'On the Other Side', May 24-26, St Petersburg, Russia.

Christensen, P. T. (2016): 'Labor Under Putin', New Labor Forum, vol. 26, no. 1, pp. 64-73.

Clarke, S. (1993): 'The Contradictions of 'State Socialism', in Clarke, S., P. Fairbrother, M. Burawoy, and P. Krotov (eds.).What About the Workers?: Workers and the Transition to Capitalism in Russia, Verso, London and New York.

Clarke, S. (1995): Management and Industry in Russia: Formal and Informal Relations in the Period of Transition, Cheltenham, Edward Elgar.

Clarke, S. (2007): The Development of Capitalism in Russia, Routledge, London.

Clément, K. (2015): 'Unlikely Mobilisations: how Ordinary Russian People Become Involved in Collective Action', European Journal of Cultural and Political Sociology, vol. 2, nos. 3-4,

211-240.

Gel'man, V. (2005): 'Political Opposition in Russia: A Dying Species?', Post-Soviet Affairs, vol. 21, no. 3, pp. 226-246. 
Greene SA and Robertson GB (2009): Politics, justice and the new Russian strike, Communist and Post-Communist Studies, vol. 43, no.1, pp. 33-54.

Hochschild, A. R. (2016): Strangers in Their Own Land: Anger and Mourning on the American Right, New Press, New York.

Kalleberg, A. L. (2009): 'Precarious Work, Insecure Workers: Employment Relations in Transition', American Sociological Review, vol. 74, pp. 1-22.

Makarkin A. (2007): 'LDPR: V piatyi raz v Dume' [trans: 'LDPR: Fifth time in the Duma'],Ezhednevnyi zhurnal, 20 July 2007, accessed 31 March 2017, http://www.ej.ru/?a=note\&id=7263\&authors=all

Mandel D (2004): Labour after Communism: Auto Workers and Their Unions in Russia, Belarusand Ukraine, Black Rose Books, Montreal, QC, Canada.

March L. (2002): The Communist Party in Post-Soviet Russia, Manchester University Press, Manchester.

March, L. (2009): 'Managing Opposition in a Hybrid Regime: Just Russia and Parastatal Opposition', Slavic Review, vol. 68, no. 3, pp. 504-527.

McAllister, I. and White, S. (2008): 'Voting 'against all' in Postcommunist Russia', EuropeAsia Studies, vol. 60, no. 1, pp. 67-87.

Monaghan, A. (2016):'What to Know About Russia's Parliamentary Elections' ChathamHouse publication, accessed 31 March 2017, https://www.chathamhouse.org/expert/comment/what-know-about-russia-s-parliamentaryelections\#sthash.PFxmHDws.dpuf.

Morris, J. (2016): Everyday Post-Socialism: Working-Class Communities in the Russian Margins, Basingstoke, Palgrave.

Morris, J. 2(017): 'An Agenda for Research on Work and Class in the Postsocialist World', Sociology Compass, vol. 11, no. 5, pp.1-12.

Morris, J. and Hinz, S. (2017): 'Trade Unions in Transnational Automotive Companies in Russia and Slovakia: Prospects for Working class power', European Journal of Industrial Relations, vol. 23, no. 1, pp. 97-112

Moscow Times, (2016): 'Statistical Evidence Suggests Russia's Ruling Party Cheated Its Way to Supermajority', Moscow Times, September 19, 2016, accessed 31 March https://themoscowtimes.com/news/statistical-evidence-suggests-russias-ruling-party-cheatedits-way-to-a-supermajority-55396.

Olimpieva, I. (2012): 'Labor Unions in Contemporary Russia: An Assessment of Contrasting Forms of Organization and Representation', Working USA, vol. 15, pp. 267-283.

Olimpieva I. and Orttung, R. (2013): 'Russian Unions as Political Actors', Problems of PostCommunism, vol. 60, no. 5, pp. 3-16.

Olimpieva, I., (2017): 'Po tu i etu storony barrikad: podkhod k issledovaniiu sotsial'notrudovykh protestov $\mathrm{v}$ Rossii' [On that and this side of the barricades: an approach to researching social-labour protests in Russia], Conference panel and roundtable discussion, 
Centre for Independent Social Research Conference 'On the Other Side', May 24-26 2017, St. Petersburg, Russia.

Smyth, R., Lowry, A. and Wilkening, B. (2007): 'Engineering Victory: Institutional Reform, Informal Institutions, and the Formation of a Hegemonic Party Regime in the Russian Federation', Post-Soviet Affairs, vol. 23, no. 2, pp. 118-137.

Stenning, A., Smith, A., Rochovská, A., and Swiatek, D. (2010): Domesticating NeoLiberalism: Spaces of Economic Practice and Social Reproduction in Post-Socialist Cities, Wiley-Blackwell Malden, MA.

Strzelecki, J. (2017): 'Painful Adaptation: The Social Consequences of the Crisis in Russia', Ośrodek Studiów Wschodnich im. Marka Karpia, Centre for Eastern Studies, no. 60, Warsaw, Poland.

TsEPR [Tsentr Ekonomicheskikh I politicheskikh reform - trans. Centre for Economic and Political Reform], (2016): 'Kak vyzhivaiut rossiskie sem'i' [trans. 'How do Russian Families Survive'], accessed 31 March http://cepr.su.

Waite, L. (2009): 'A Place and Space for a Critical Geography of Precarity?' Geography Compass, vol. 3, no. 1, pp. 412-433.

Williams, C. C., (2008): 'Beyond Necessity-Driven Versus Opportunity-Driven Entrepreneurship', The International Journal of Entrepreneurship and Innovation, vol. 9, no. 3, pp. $157-165$. 